371.3::811.163.41

37.018.43:004.738.5

https://doi.org/10.18485/kij.2020.67.1.10

СЛОБОДАН Б. НОВОКМЕТ*

Институт за српски језик САНУ

Београд
Оригинални научни рад

Примљен: 26.05.2020.

Прихваћен: 05.06.2020.

\title{
КАКО НАМ ИНТЕРНЕТ МОЖЕ ПОМОЋИ У НАСТАВИ СРПСКОГ ЈЕЗИКА И КЬИЖЕВНОСТИ?**
}

\begin{abstract}
Предмет овог рада је сажети преглед ресурса доступних на интернету који умногоме могу олакшати рад наставницима и професорима српског језика и књижевности у припреми часова, пројеката, радионица и секција из језика и књижевности у времену када настава све више излази из традиционалних оквира и ослања се на електронско учење. Посебан осврт у овом раду биће на онлајн лексикографији (доступним електронским речницима српскога језика на интернету), улози друштвених мрежа у припреми часова, као и препоруци едукативних сајтова и блогова чија је улога, између осталог, усмерена ка неговању језичке културе српског језика.
\end{abstract}

Кључне речи: интернет, настава српског језика и књижевности, онлајн лексикографија, блогови, сајтови, правопис.

\section{1. Уводна разматрања}

1.1. Свакодневно смо сведоци све интензивнијег развоја модерне информационе технологије која утиче на све сегменте људске делатности, те њеног убрзаног и незанемарљивог уплива на образовање. Зато није ништа необично што настава српског језика и књижевности у основним и средњим школама, у складу са захтевима времена, све више излази из оквира традиционалног приступа, који подразумева интеракцију наставника и ученика, и окреће се ресурсима које је омогућила и популаризовала дигитална револуција у 21. веку. Отуда у последње време присуствујемо развоју онлајн или електронског учењ $а$, које подразумева извођење образовног процеса уз помоћ информационо-комуникативних техно-

*slobodan.novokmet@isj.sanu.ac.rs

** Рад је заснован на радионици која је одржана 8. фебруара 2020. године на 61. Републичком зимском семинару за наставнике и професоре српског језика и књижевности, на Филолошком факултету у Београду. 
логија, у шта убрајамо: наставу на даљину (тзв. онлајн наставу) преко дигиталних платформи (као што су Zoom или Moodle); предавања која су прилагођена интернету (разни вебинари, веб-кастови, туторијали); електронске књиге (енгл. e-books), а наставницима и ученицима доступни су различити сајтови, друштвене мреже и базе података, од речничких платформи до едукативних блогова и портала који се баве језиком, културом и књижевношћу. Осим тога, дигитални уџбеници (који се налазе у понуди већине издавачких кућа) и дигиталне табле, као и таблети, већ неко време нису новина у нашем образовном систему. При томе, „развој технологије и алата иде у смеру поједностављивања њиховог коришћења на начин да они постају доступни све ширем кругу људи који се баве едукацијом, без обзира на информатичко предзнање" (Матасић/Думић 2012: 145). С обзиром на то да ове методе омогућавају интеракцију различитих мултимедијалних садржаја који подразумавају спој текста, слике, звука, анимације, филма и сл., и да подстичу већу мотивисаност и интересовање ученика, као и бољу приступачност садржаја који су некада били тешко доступни, верујемо да се налазимо на прагу важне револуције у приступу образовању.

1.2. Један од циљева овог рада јесте да пружи наставницима и професорима српског језика, као и њиховим ученицима, увид у неке од доступних дигиталних ресурса који се могу лако имплементирати у различите аспекте извођења наставе српског језика и књижевности, било да је у питању сама припрема часова или различитих пројектних задатака, додатне наставе, тестова за такмичење или секција, и који се могу користити без икаквих напредних информатичких компетенција. С тим у вези, рад делимо на четири сегмета који ће бити део наше анализе. У питању су: онлајн лексикографија; онлајн правопис; сајтови, портали и блогови; друштвене мреже.

\section{2. Онлајн лексикографија}

2.1. „Намена и корисност речника вишеструка је, за многе области (предавање и учење матерњег и страног језика, превођење, лектуру, у масовним медијима, књижевности, психологији, филозофији, социологији и многим др.), па је и број њихових корисника већи него било којег другог језичког дела" (Лазић Коњик/Јелић 2009: 115), а о важности укључивања речникаิ српског језика, поготово Речника САНУ, у наставу српског језика и књижевности са становишта акцентологије, морфологије, синтаксе и лексикологије већ смо раније писали (в. Новокмет/Богдановић 2015).

2.2. Под онлајн лексикографијом подразумевамо речнике доступне на интернету. Не ради се о традиционалним речницима затвореног типа који се најчешће у формату pdf (енгл. Portable Document Format) могу пронаћи, без ауторских права, на различитим веб-адресама (понекад без могућности претраживања), већ о модерним електронским (онлајн) речницима који су креирани и објављени на интернету и имају претраживе базе најразличитијих лексикографских пода- 
така. Модернизација српске лексикографије је већ више од деценије један од приоритета савремене србистике, а о потреби за таквим онлајн речницима различитих типова и намене посведочиће сваки истраживач који се бави било којим аспектим филологије. „У многим развијеним земљама лексикографија се сад већ у појмовном смислу изједначава с електронском лексикографијом, дајући тако електронским речницима и дигиталним издањима речника примат над папирним, штампаним издањима” (Милосављевић/Новокмет/Тодић 2019: 313). ${ }^{1}$ Охрабрује и све веће залагање различитих установа (посебно Института за српски језик САНУ) да дигитална хуманистика и, пре свега, дигитална лексикографија сасвим заживи, у шта спада и рад на дигитализацији грађе за израду Речника CAHУ, која ће убрзати рад на самом Речнику, као и рад на образовању доступне онлајн веб-платформе за претрагу РСАНУ. Иако се ситуација поправља, видљиви су проблеми од раније. Од неких пројеката онлајн речника се одустало, неки су још увек у фазама израде, а неки од њих својим „садржајем, обимом, фондом и лексикографском обрадом речи, могућностима претраживања и сл. незадовољавају просечног, камоли стручно профилисаног корисника (нарочито језички образованог) (Лазић Коњик/Јелић 2009: 114).

2.3. Оно што наставницима, али и ученицима може олакшати приступ Речнику САНУ, као и Речнику $M C$ засада јесте платформа Електронски речник српског језика на адреси http://www.srpskijezik.com/. Платформа је претражива по одредницма и нуди још корисних претраживачких опција (нпр. по граматичким квалификаторима, терминолошким скраћеницама, дефиницијама итд.), а њена речничка база за српски језик углавном се састоји од 18. томова Речника СAHУ, претворених у електронски облик и допуњених одредницама из Речника $M C$. Иако се стиче утисак да је овом методом направљен целовит речник српскога језика, јасно је да је приступ „спајања” два дескриптивна речника различитих по својој концепцији, методологији, намени и обиму проблематичан и да, поготово у истраживачким задацима, не може да замени штампана издања ових лексикографских дела. Међутим, засада је ово једини начин да се ова два речника ефикасно претражују на интернету.

2.4. Други тип дескриптивног једнојезичног речника српскога језика који је доступан на интернету јесте Викиречник на адреси http://sr.wiktionary.org/wiki. У питању је речник замишљен као база коју уређују сами корисници по принципу функционисања и најпопуларније интернет енциклопедије Википедија. О предностима и манама овог лексикографског пројекта, као и о могућностима краудсоурсинг (енгл. crowdsoursing) методологије у лексикографији, већ се код нас писало (в. Лазић Коњик/Јелић 2009; Милосављевић/Новокмет/Тодић 2019). Оно што можемо да додамо јесте да овакав тип речника, посебно због богатства граматичких информација које пружа (а које код одређених одредница подра-

${ }^{1}$ „Као неке од предности електронских речника над штампаним издањима речника наводе се мултимедијалност, интерактивност, лакше и боље претраживање корпуса, већа доступност грађе и лексикографских информација и др.” (Милосављевић, Новокмет, Тодић 2019: 313). 
зумевају и изговор, акценат, падежну парадигму и сл.) и постојања одређеног методолошког приступа може послужити наставницима и ученицима у решавању тренутних недоумица у вези са различитим граматичким карактеристикама речи, међутим, због ограничених семантичких дефиниција, као и општих проблема који се тичу оваквог типа речника, а који подразумевају мањак информација о ауторима, обиму, намени, корпусу, изворима и сл., не треба га узимати као једини и поуздан извор лексикографских информација.

2.5. Слично може да се каже за још један једнојезични речник српског језика на интернету, а то је Вокабулар, доступан на адреси http:/www.vokabular.org. Иако замишљен као „општи српско-српски речник”, који треба да служи као слободан сервис доступан свим заинтересованима, утисак је да је овај пројекат из 2005. године већ неко време у фази стагнације (и даље стоји ознака „бета” у његовом наслову). Међутим, једноставном претрагом јасно је да је база овог онлајн речника похрањена речима страног порекла (вероватно из Лексикона страних речи и израза М. Вујаклије), те га наставницима и ученицима можемо препоручити за брзу проверу значења непознатих речи страног порекла и њихове етимологије, нарочито различитих интернационализама из старогрчког и латинског језика. Претрагом основних одредница (као што је нпр. потенщијал) добијамо упућивање и на терминолошке изразе који се могу повезати са том одредницом (као нпр. потенцијална енергија, потенцијална котурача и сл.).

2.6. За наставнике и ученике посебно може бити занимљива платформа Рacковник, доступна на адреси http://raskovnik.org/, која се развија као један од потпројеката на Институту за српски језик САНУ. Расковник је, пре свега, посвећен дигитализацији српског речничког наслеђа, и на њему се тренутно налазе потпуно претраживи следећи речници: Српски рјечник Вука Ст. Караџића, Речник косовско-метохијског дијалекта Глише Елезовића, Речник говора јужне Србије Момчила Златановића, Речник говора Прошћења Милоша Вујичића и Речник дубровачког говора Михаила Бојанића и Растиславе Тривунац. Као платформа за упоредна истраживања српске лексике, Расковник тренутно пружа неколико напредних претраживачких опција, а намера је да у догледном периоду обухвати више дијалекатских и других специјалних речника. Управо дијалекатски речници могу наставницима и ученицима пружити важне лексичке информације при обради дела која су везана за територијално специфичне говоре, као што су она Боре Станковића или Стевана Сремца, а значај могућности брзе и лаке претраге Српског рјечника у настави српског језика и књижевности не треба посебно наглашавати.

2.7. Иако се Вукајлија, доступан на адреси http://vukajlija.com, често види као „речник шаљивог садржаја” који нема лексикографски значај (в. Лазић Коњик, Јелић 2009: 116), у последње време богатство његове базе пружа занимљиве могућности за језичка истраживања различитог типа. С обзиром на то да су у овом онлајн лексикону „протумачени појмови, личности, догађаји и сл. изразних области људске делатности, односно појаве условљене културом и 
традицијом нашег народа" (Милосављевић/Новокмет/Тодић 2019: 319), богатство садржаја, који су такође креирали сами корисници и посетиоци сајта, пружа прилику за истраживачке задатке који се могу бавити жаргоном српског језика или разговорним стилом. Тако су 2019. године полазници семинара „Жаргонизми, фразеологизми, дијалектизми у односу на стандардни језик”, који се одржао у Образовно-културном центру „Вук Караџић” у Тршићу, добили задатак да користећи сајт Вукајлија сакупе и анализирају грађу која би обухватила нове и незабележене фразеолошке јединице у српском језику. Користећи традиционалне приступе у ексцерпцији и анализи фразеолошке грађе, полазници курса издвојили су више десетина занимљивих примера који ће, можда у будућности, наћи своје место у неком фразеолошком речнику. ${ }^{2}$

\section{3. Онлајн правопис}

3.1. Поред Правописа српскога језика Матица српске, његових школских издања, различитих приручника и уџбеника из граматике српског језика, већина корисника интернета покушава да своје правописне недоумице решава на за то специјално оформљеним језичким групама на друштвеним мрежама. Осим тога, једини веб-сајт који нуди потпуно претраживе правописне недоумице јесте Како се пише на адреси https://kakosepise.com/. Под претраживом базом на овој платформи подразумева се опција која дозвољава корисницима да укуцају тражену реч или конструкцију, чак и погрешно написану, и провере како се она правилно пише у српском језику. То значи да корисник може да укуца нпр. потпредседник, подпредседник или потпретседник, и да у сваком од тих случајева добије тражени одговор са кратким објашњењем правила. Поред индекса појмова, још једна опција која може бити од користи истраживачима правописних питања јесте категорија Најчешће, која бележи које недоумице су корисници најучесталије претраживали на овом сајту. ${ }^{3}$ И поред несумњиве користи које оваква претражива база на интернету доноси, поготово ученицима који чак и преко мобилних телефона могу да провере неко правило, као главну ману издвајамо њену ипак ограничену базу која се састоји из типизираних примера и недоумица који се могу наћи у Правопису српскога језика. Читав низ правописних проблема новијег датума у које спадају писање полусложенца (нпр. сајбер кафе, таблет рачунар и сл.), појмова из науке, технике и информационих технологија (Вајбер или Вибер, Јутјуб или Јутуб и сл.), разна питања транскрипције (Мареј или

2 Занимљиво је да су полазници курса, иначе талентовани средњошколци из Србије, у оквиру овог задатака нашли више фразеолошких јединица које су већ дуго потврђене у говорној пракси иако их не бележи ниједан речник српског језика, као што су нпр. имати две леве ноге, бацати некога у ребус, имати змијско тело и др.

${ }^{3}$ Нажалост, поразно делују подаци који у врх најчешће постављених питања сврставају она која су део правописних лекција у нижим разредима основне школе, као што су нпр. самном или са мном (1106664 упита), не знам или незнам (779050 упита), уреду или у реду (778943 упита), небих или не бих (657961 упита) итд. 
Мари, Хоакин или Јоакин) и писања великог слова овде нису заступљена. То је донекле и оправдано, јер је немогуће очекивати да се оваква база свакодневно допуњује новим и актуелним примерима (што би ипак требало да буде њена предност), за чије решавање је ипак неопходно примењивати и тумачити већ постојећа правила.

\section{4. Сајтови, портали и блогови}

4.1. У другој деценији 21. века постало је очигледно да активним корисницима интернета у Србији недостаје садржаја који ће се непосредно бавити српским језиком и језичком културом (чему је донекле допринело и ограничено интересовање медија за питање језика) ${ }^{4}$ (в. Новокмет, Слијепчевић 2012). Смањен ниво културе јавног говора и писања био је све очигледнији, стручна литература је била махом неприступачна ширим корисницима, а појавила се потреба да се на дневном нивоу тумаче и коментаришу различита, пре свега јавна, огрешења о језичку норму српског језика. Отуда је новонастала празнина у медијском простору попуњена оснивањем многобројних сајтова, блогова и портала који се баве српским језиком и језичком културом.

4.2. Од сајтова и портала који се још увек активно баве популаризацијом језичке културе можемо да поменемо Језикофил (доступан на адреси http://jezikofil.rs/), Српски језички атеље (http://www.srpskijezickiatelje.com/) и Описмени се (https://www.opismenise.com/). Иако је сврха сва три сајта решавање језичких недоумица, они се ипак концепцијски разликују. Портал Описмени се је углавном посвећен решавању традиционалних проблема у правопису и граматици српског језика, као и популаризацији српске књижевности, а неко време нудио је и читаоцима прилику да објављују своје текстове на разне језичке теме. С друге стране, „Језикофил од осталих портала и језичких група разликује, поред сталне сарадње са стручњацима, најпре афирмативан приступ (избегнуто је да се сајт претвори у прикупљање огрешења о језичку норму и њено исмевање, чему могу бити склони корисници Фејсбука), а затим, актуелност тема (прате се и други медији и реагује се на актуелна друштвена, културна и политичка дешавања која утичу на језик)" (Николић/Слијепчевић/Новокмет 2018: 64). Предност Језикофила је и стална комуникација уредника и аутора прилога са читаоцима, која се огледа у стотину мејлова и коменатара који се размене на годишњем нивоу. На крају, Српски језички атеље, како сами уредници кажу, има циљ да „људе који проводе време на интернету, а и оне друге, приволи нашој граматици, правопису, семантици и основним појмовима о језику; да им брзо и лако да поуздане информације о језичким појавама, засноване на стручној ли-

\footnotetext{
${ }^{4}$ У једном тренутку од језичких емисија у медијима широј публици познате су биле само Пут y речи на Радио Београду 2 и Српски на српском на Радио Београду 1, а лингвисти као што су Иван Клајн, Рада Стијовић и др. имали су редовне прилоге у листовима као што су Политика, НИН и сл., док су језичке теме у другим штампаним медијима биле ретке или спорадичне.
} 
тератури", међутим предност овог сајта је и активан Форум, на којем се могу пронаћи врло подстицајне расправе и разговори корисника на разна језичка питања подељена по областима као што су Правопис, Граматика, Семантика и етимологија, Превођене, Језик и информатика, Книжевност.

Од сајтова треба истаћи још и Лексиком (на адреси http://lexicom.rs/Default.aspx) нашег истакнутог лингвисте Владе Ђукановића, који садржи потпуно претражив Морфолошки речник српског језика (и по основним и по изведеним облицима речи), намењен свима који желе да пронађу неку реч српског језика и виде све њене облике. Тренутно је на интернету ово једини претраживи морфолошки речник који може решити многе недоумице у вези са падежним парадигама именица у једнини и множини.

4.3. Блогови такође могу бити вид популаризације језичке културе. Њих обично воде наставници или професори, а теме могу да се крећу од оних које се баве школском свакодневицом до уско специјализованих који су посвећени решавању језичких недоумица, какав је нпр. Питајте лектора (https://www. pitajtelektora.com/). Посебно вреди истаћи и блог https:/abc.amarilisonline.com/, који се, иако је првенствено намењен учењу немачког и енглеског језика, издваја и својим одељком посвећеним српском језику у коме се могу наћи многе занимљиве теме из српске етимологије и лингвокултурологије (од порекла различитих израза до исхране у Србији у 19. веку). Блог који такође треба издвојити јесте Како Јеца каже (https://kakojecakaze.com/), који осим језичких тема нуди јединствен поглед на школски живот из угла једног наставника српског језика, бавећи се притом и низом тема које се тичу примене дигиталних технологија у настави. Такође, похвално је и све чешће активирање наставника српског језика на Јутјубу (https://www.youtube.com/). Користећи ову глобално популарну платформу за дељење видео-записа не би ли снимали своја предавања из језика и књижевности, предавачи из основних и средњих школа доказују да класично образовање не мора да буде физички везано за учионицу, већ га чине доступним ученицима на начин који је модеран, прагматичан и који остварује блиску интеракцију са генерацијама одраслим на интернету.

\section{5. Друштвене мреже}

5.1. Друштвене мреже постале су у последњих десетак година дигитални простор окупљања великог броја људи (само у Србији постоји четири милиона налога на Фејсбуку, док је Инстаграм забележио два милиона корисника у 2018. години). Популарност друштвених мрежа условила је да се корисници лако организују и окупљају око одређених интересовања, а језик је једна од најпопуларнијих тема и разлог оснивања великог броја тзв. језичких група (које неретко броје и више десетина хиљада чланова). Разлози за њихово оснивање слични су

${ }^{5}$ У једном тренутку на Фејсбуку је функционисало више од десет језичких група, само неке од њих су: Нама вољена граматика, Борба за правопис, Буди писмен, Правопис без муке, Дневна доза 
онима које смо поменули у претходном поглављу (одсуство језичких тема у медијима), али њихову популарност треба тражити, пре свега, у потреби за брзим и ефикасним решавањем језичких недоумица и неприступачности (или недовољном познавању) референтне литературе, тј. правописа, приручника, речника и сл. Њихова функција јесте „решавање језичких недоумица и језичких проблема корисника [...] од коментарисања актуелних дневно-политичких тема које имају језичку мотивацију (различити језички лапсуси, грешке и пропусти који се могу чути у медијима) до дефинисања нових, непознатих, страних, жаргонских, варијантних речи и неологизама" (Милосављевић/Новокмет/Тодић 2019: 323). Предност језичких група у последње време огледа се и у постављању језичких анкета (отвореног или затвореног типа) које осим решавања непосредних недоумица могу донети и више креативних одговора на одређене упите, с обзиром на то да су чланови група углавном заинтересовани за питања језичке културе и норме и прате догађаје везане за језик и језичку културу (једна од актуелних анкета односила се на то како одсада треба звати становнике Холандије, а одговори су нпр. били Низоземунц̧и, Марихуанцฺи, Низоземљани, Низоземљаци, ниски земљаци и сл.).

„Проблем оваквих група је отежана претраживост и расплинутост садржаја (корисни предлози бивају утопљени у бројне сувишне, непотребне информације, коментаре, одговоре који понекад прелазе у личне разговоре обојене афективним тоновима), као и непостојање јединствених база у које би се сакупљали и класификовали предлози и одговори” (Милосављевић/Новокмет/Тодић 2019: 323). Међутим, наставницима и ученицима могу бити корисне оне групе које већ годинама одржавају сталан квалитет рада и администратора, редовно доносе нове теме и чији су чланови непосредно активни, а то су: Свакога дана по једно правило из области језичке културе, Наш језик, Правопис и граматика српског језика, Акиенти савременог српског језика и језичка култура и Језичке недоумице.

5.2. Инстаграм, као друштвена мрежа окренута пре свега визуелним садржајима, нуди свеж приступ у ширењу и неговању правилног језичког изражавања и језичке културе. У последње време на Инстаграму се оснива на десетине нових профила ${ }^{6}$ чији је циљ да на различите начине, пре свега у садејству слике и текста, образложе неко правило или популаришу неку језичку или књижевну тему. Профили који са посебном пажњом воде рачуна о квалитету визуелног и тематског садржаја јесу, пре свега, srpskicaskom, bojan_jokanovic_ilustracije i jezikofil_rs. Сваки од ових профила различитим приступима покушава да придобије кориснике заинтересоване за питања језичке културе, било да су у питању духовите стриповске карикатуре и ситуације или чак исечци из актуелних филмова и серија који илуструју текст посвећен језичкој или књижевној теми. На

правописа, Политичко-језичке недоумище западног Балкана, Борба против неписмености, не хвали ти ништа... фали ти, Научимо правопис! Бесплатно решите своје правописне недоумице! итд.

${ }^{6}$ Само неки од њих су нпр. srpskisvuda, srpski_bez_po_muke, naucimo srpski, azbukologija, ucimo_srpski_jezik, sovica_bez_puskica, jezikogram, srpski svuda, srpski za sve и сл. 
профилу jezikofil_rs новина су нпр. дани посвећени богатству наших дијалеката, те се корисници Инстаграма упознају са махом непознатим примерима дијалектизама, као што су пљескун, басташан, броћав, чаврљуга, чербајатан, вртиваган, шукљив и сл., а у оквиру рубрике Путопис читаоцима се представљају занимљиве лингвистичке информације о светским језицима (нпр. којим језиком говори највише људи на планети, колико има живих језика на свету и сл.).

\section{6. Закључна разматрања}

6.1. Као што можемо да видимо, богатство различитих ресурса на интернету посвећених српском језику и књижевности, пружа наставницима и професорима прилику да осавремене приступ овом предмету. Укључивање у наставни процес, пре свега, речничких база, али и сајтова, блогова, друштвених мрежа и сл., може подстаћи ученичку мотивацију и истраживачки дух, учинити учење разноврснијим, али и пружити наставницима неопходне алате за лакшу припрему часова, такмичења, секција и сл. Међутим, иако одређени садржаји, као што смо видели, постоје, они су неретко резултат прегалаштва и мотивације стручних појединаца (или у случају речничких база резултат активности више корисника). Оно што изостаје јесте више доступних алата и база иза којих би стајале институције и професионални тимови, као што је нпр. база српских књижевних дела Антологија српске кюижевности Учитељског факултета у Београду, на адреси http://www.antologijasrpskeknjizevnosti.rs/, Дигитална библиотека Филолошког факултета (http://www.fil.bg.ac.rs/lang/sr/biblioteke/digitalna-biblioteka/) или поменути Расковник. Без материјалне и институционалне подршке и залагања релеванатних установа многи од ових пројеката не могу да опстану.

\section{ЛИТЕРАТУРА}

Лазић Коњик/Јелић 2009: Ивана Лазић-Коњик, Маријан Јелић, О речницима српског језика на интернету, Примењена лингвистика, бр. 10, Београд - Нови Сад, 115-128.

Матасић/Думић 2012: Iva Matasić, Saša Dumić, Multimedijske tehnologije u obrazovanju, Medijska istraživanja, god. 18, br. 1, 143-151.

Милосављевић/Новокмет/Тодић 2019: Бојана Милосављевић, Слободан Новокмет, Бојана Тодић, Онлајн речници и народна лексикографија, Језици и културе у времену и простору VIII/1, Филозофски факултет, Нови Сад, 313-325.

Николић/Слијепчевић/Новокмет 2018: Марина Николић, Светлана Слијепчевић, Слободан Новокмет, Језичко нормирање и интернет, Наука без граница - Међународни тематски зборник, Филозофски факултет, Косовска Митровица, 57-68. 
Новокмет/Богдановић 2015: Слободан Новокмет, Маријана Богдановић, Примена Речника САНУ у настави српског језика и књижевности, Кюижевност и језик 62/1-2, Београд, 173-189.

Новокмет/Слијепчевић 2012: Слободан Новокмет, Светлана Слијепчевић, О језичким недоумицама корисника друштвене мреже Фејсбук, Језик, књижевност, комуникација. Језичка истраживања, Филозофски факултет, Ниш, 199-212.

Slobodan B. Novokmet

HOW CAN WE USE INTERNET FOR LEARNING SERBIAN LANGUAGE AND LITERATURE IN SCHOOLS?

\section{Summary}

The subject of our paper is review of digital tools and contents available on internet which professors of Serbian language and literature could use for various purposes, from teaching school classes to preparing students for exams, projects, competitions etc. We are going to talk especially about online lexicography (online dictionaries available on the internet), the part of social networks in education and various websites and blogs with a roll of popularization of Serbian language and literature on internet.

Key words: internet, Serbain language and literature, online lexicography, blogs, websites, ortography. 